\title{
RELUCTANT ENTREPRENEURS OF THE RUSSIAN FAR EAST: ANOTHER VIEW ON THE ECONOMIC STRATEGIES OF ENTREPRENEURS
}

\author{
Aimar Ventsel \\ Senior Research Fellow \\ Department of Ethnology, University of Tartu \\ e-mail: aimar.ventsel@ut.ee
}

\begin{abstract}
Research into private businesses in post-Soviet Russia began with the collapse of the Soviet Union. This paper focuses on a specific segment of private entrepreneurs who I call 'reluctant entrepreneurs', and revises the concept of a 'new entrepreneurship' in Russia. The people under study entered into business reluctantly in the early 1990 s, when salaries in state jobs were not paid. The majority of these entrepreneurs planned to either return to a public-sector job or maintain their affiliation with the state enterprises. This attitude contradicts the dominant approach in academic writing, in which private entrepreneurs in post-socialist countries see entrepreneurship as a new perspective and an act of self-fulfillment. The strategy of the entrepreneurs under study is also oriented against constant expansion and innovation. Moreover, in their activities entrepreneurs are led by local social norms that do not often support the earning of direct profit. Such practices are caused by the current economic climate in Russia, where the state shows little interest in the activities of small and medium-sized entrepreneurs. This article suggests that there is a need for new conceptual tools to analyze these facets of the private economy.
\end{abstract}

Keywords: informal economy, kinship, Russia, Sakha, small and medium entrepreneurs

The defining line between the socialist society and 'what came next' is apparently when the former 'economy of shortage' was transformed into a market economy, and entrepreneurship was officially legalized (see Verdery 1993, 1996). With the collapse of the socialist planned economy in Eastern Europe there emerged an entrepreneurial class associated with the Weberian tradition, and the appearance of a fundamental need for innovation, free thinking, and democracy (see Davidova \& Thomson 2003; Estrin \& Aidis \& Mickiewicz 2007; Gibson 2001; Peng \& Shekshnia 2001; Wegren 2000). At least in the Russian case, 
the enthusiastic expectations remained unfulfilled. While entrepreneurship in Russia has taken on different forms, it is rather related to the shadow economy, struggle, and crime than to any kind of free thinking or democratic ideology (see Cartwright 2001; Humphrey 2002; Kuznetsov \& Kuznetsova 2005; Tarasov \& Egorov \& Kulakovskii 2013; Ventsel 2005). However, the private economy continues to thrive, and plays an important role in everyday life in Russia. After private enterprise had been sanctioned in the Soviet Union in the late 1980s (McCarthy \& Puffer \& Shekshnia 1993: 128), it expanded quickly over the whole region and reached the easternmost territories in the early 1990s.

This article focuses on a segment of entrepreneurs in the Russian Far East, who I call 'reluctant entrepreneurs'. Such entrepreneurs often took up their new occupation not because they dreamed of becoming entrepreneurs, seeking a new trajectory in the life, but because biznes seemed to be their best option for survival in the $1990 \mathrm{~s}$, when government salaries remained unpaid, and the social security system was drastically dismantled (cf. Rasell 2009). With a few exceptions, people did not plan to be engaged in entrepreneurship their whole lives, but wished to return to the public sector. Many of them divide their time between their own enterprises and state-paid jobs. Moreover, their views on profit and expansion might contradict Western theories on leading a business successfully. As I show, such entrepreneurs are not an anomaly, and their strategies and logic are fully understandable given the current state of the market economy in Sakha-Yakutia.

\section{THE REPUBLIC OF SAKHA (YAKUTIA) AND ITS ECONOMIC ENVIRONMENT}

The Republic of Sakha (Yakutia) is the largest territorial unit of the Russian Federation and belongs to the easternmost administrative unit, the Far North Federal District, which is comprised of nine different territorial units. The republic is a large but sparsely populated territory covering more than three million square kilometers, with slightly less than a million people, 55 percent of whom are the titular ethnic group, the Turkic speaking Sakha. Approximately 73 percent of the population in the Republic of Sakha are urban.

The republic is famous for its diamond resources, producing 30 percent of the world's diamonds and almost 100 percent of Russia's diamonds. In addition to diamond mining, the Republic of Sakha has significant resources including gold, gas, oil, precious metals, coal, and timber. Natural resource extraction is the domain of big companies in the region, as is large-scale construction. The 
difference is that while mining and oil extraction are dominated by state-owned companies, in the construction sector private companies have the upper hand.

The official definition of medium or small enterprises remains blurred and changes constantly, but in 2009 181,514 small enterprises ${ }^{1}$ existed in the Russian Far North (Stepanova \& Nogovitsyn 2011: 49). Approximately 80 percent of these were "microenterprises" or enterprises that hired up to fifteen employees on a permanent basis. It must be mentioned that in relation to the number of enterprises per capita, the Far North is slightly below the average Russian level. In terms of regional distribution, about 47 percent of small enterprises are located in Primorsky Krai, 19 percent in Khabarovsk Krai, and approximately 8 percent in the Republic of Sakha (Yakutia) (ibid.: 49-59). Small enterprises tend to have very low investment and profit levels, and 60 percent of the small enterprises in the Russian Far North are engaged in wholesale and retail sales (Egorov 2006: 192; Stepanova \& Nogovitsyn 2011: 65).

In 2010, there were 115 medium-size enterprises and 4,952 small enterprises registered in the Republic of Sakha; from these 4,029 were classified as microenterprises. In the year 2009, small enterprises contributed only 6.6 percent of the regional GDP but gave work to 40 percent of the local workforce. In the Republic of Sakha, 80 percent of small and medium enterprises are concentrated only in four cities (the capital, Yakutsk; Neriungri, famous for its coal industry; Mirnyi, the center of diamond industry; and Lensk, another center for diamond mining). From the regional enterprises 400 are agricultural. The statistics shows that in Sakha 44.4 percent of small enterprises are engaged in wholesale merchandise, 22.7 percent in construction, 6.8 percent in real estate, and 5.7 percent in transport. The role of small-scale enterprises in different spheres can be high: 94.3 percent of services (bytovye uslugi) and 100 percent of the small bus transport market belongs to small enterprises, as does the majority of tourism, clothing repair, cargo transport, car and truck repair, and other services.

The low profit levels of such enterprises can be explained by the underdeveloped infrastructure and high energy costs in the region. Local economists have highlighted one peculiarity of small-scale enterprises: their need for highly skilled specialist labor is much lower than their demand for unqualified manual labor. Notwithstanding several federal and regional programs, the state has been unsuccessful in developing 'innovative' and modern high-tech small enterprises. In general, the statistics show that between 2004 and 2009 only 29 innovative small enterprises were established in the republic (Stepanova \& Nogovitsyn 2011: 56-57). As some local scholars argue, the reason is that big mining and production companies, with better financing and market pros- 
pects, dominate these spheres already and offer better salaries than a private enterprise (ibid.: 59).

This article draws on the fieldwork conducted in the Republic of Sakha in July and December 2013, and in July 2014, and personal extensive background knowledge of the region obtained over the last sixteen years. Each time, I spent three to four weeks in the region, conducting research mainly in the capital of Yakutsk, but also in villages near Yakutsk and in the Verkhoyansk district (approximately 1,000 km northeast from Yakutsk). During the fieldwork we recorded twelve formal interviews ${ }^{2}$ with different entrepreneurs whose enterprises were classified as small or microenterprises. Interviews were also made with different government officials, including one former Minister of Economy of the Republic of Sakha. Additionally, I talked to various other entrepreneurs, visited their enterprises, and observed how they operated. All but one entrepreneur had started their business out of necessity in the 1990s. One woman was the spouse of a wealthy businessman, whose husband funded her bridal shop because, as she put it, she had always dreamed of such a store. Nevertheless, she also perfectly fitted the ideal, sharing similar attitudes and behavior patterns with other subjects. Entrepreneurs under study were engaged in various sectors: fishing and hunting enterprises, food shops, laundries, construction firms, tourist ventures, and a hair salon. Some of the informants had different small enterprises, none of them had studied the profession they were engaged in at the time of the encounter, and for all the respondents their current enterprise was not their first but rather a third or fourth one. All but one were ethnic Sakha (one was Armenian), half of my respondents originated from a village, roughly 70 percent were women, and their age varied from mid-thirties to late fifties. Statistics presented in this article came from the works of local economists.

\section{CONCEPTUAL CONFUSION}

Existing studies on private entrepreneurship in Eastern Europe reveal huge gaps when it comes to the question about what motivated the actors to start their biznes in the first place. Notwithstanding that researchers who study entrepreneurship tend to be critical to the utilitarian approach of the neoclassic economy (Nee \& Young 1991), ${ }^{3}$ the general impression given by academic literature is that individuals embraced their new occupation more or less voluntarily, and even with some degree of enthusiasm. Indeed, studies of entrepreneurship in post-Soviet Russia and grounded in anthropology (Hann 2000; Köllner 2013 [2012]), economics (Berkowitz \& DeJong 2001; Estrin \& Aidis \& Mickiewicz 2007) and sociology (Barsukova \& Radaev 2012; Sakaeva 2012) indicate indi- 
rectly that the actors saw the new market economy as an opportunity. Another popular argument in academic literature is the 'path dependency' argument, an assumption that entrepreneurs have role models, have been active in the business previously, or that new post-socialist enterprises follow the footsteps of similar state companies of the socialist period (Alanen et al. 2001; Nee \& Young 1991; Pickles \& Smith 1998; Stark 1991). In general, one expects that a person who enters into a small business possesses the wish to be engaged in entrepreneurship, and has some vision or strategy as to how they will develop the business. All these explanations are more or less questionable regarding the nature of a private business in the late Soviet Union and the first post-Soviet period. Indeed, people who changed occupation to open a kiosk or a private cafe had virtually no role model, and very little understanding of how to operate in a - principally unregulated - market economy. Another approach which raises an eyebrow is that many researchers continue to speak about the 'new' private entrepreneurship even when it has existed for more than a decade or two (see, e.g., Kuznetsov \& Kuznetsova 2005; Polischuk 2001). ${ }^{4}$

One theoretical framework analyzing entrepreneurship in Russia, relied on by various authors, is the concept of blat (clout, profitable connections). The impression, when revising literature on the topic, is that blat is a natural part of Russian private business. Russia is described as a 'network state' (Humphrey 2012), where political and economic networks can have a semi-feudal nature (Gambold Miller 2003; Shlapentokh 2007). The originator of the academic concept of blat - Alena Ledeneva - argues that it was a Soviet era strategy, a system of favors, to gain access to scarce resources, mainly goods (Ledeneva 1998, 2006). Blat is usually viewed as a circle of people engaged in a delayed reciprocity. This circle is a closed one and based on a 'negative solidarity' or mistrust of outsiders (Radaev 1998, 2005). Moreover, the reciprocal group can be seen as a network of people with common interests, based on pragmatic calculations, and not on kin, clan, or other social or cultural ties. Proponents of the concept admit that the nature of blat has changed and it has shifted from the economy of favors to a cash economy, since access to goods in Russia is now limited by one's wealth and not by availability. In general, modern blat in academic literature is interpreted as an informal network linking entrepreneurs and political power structures (Puffer \& McCarthy \& Boisot 2010). Via such connections, entrepreneurs can exploit state resources or sign profitable deals with state structures, for example ministries (Hsu 2005). Indeed, post-Soviet Russian history is full of corruption scandals where private enterprises receive overpaid orders to build, supply the government institutions with company cars, software, and so on. ${ }^{5}$ 
When in the Soviet era blat had a certain ideological aspect, then today it is seen as purely economic networking (Ledeneva 2008). Blat is described as a predatory behavior against those who are outside the circle (Hsu 2005: 312). Ledeneva (2008: 130) even argues that it is an individualistic, not communitarian practice, where every participant acts solely out of their own interests. This statement is in accordance with the view that Russia is largely a 'distrustful society' (Estrin \& Aidis \& Mickiewicz 2007). Nevertheless, it is difficult to agree to Ledeneva's statement that the word blat is hardly used today and people prefer other terms. In the Republic of Sakha, at least, the word is used to indicate exactly the same kind of corruption that links governmental and entrepreneurial networks. The expression is, however, rarely used to describe reciprocal practices between ordinary people or private enterprises. It is not the topic of this article, but blat is hardly a Maussian gift exchange as some authors argue (Hsu 2005; Humphrey 2000; see also Ssorin-Chaikov 2000), but rather a cynical and sinister patron-client relationship.

For the abovementioned reasons, blat as a concept seemed unsuited for the analysis of the attitudes, strategies, and practices of the entrepreneurs examined. While blat is in some sense a 'genuine Russian' phenomenon, more suited for the purpose of this article is the 'genuine Chinese' concept of reciprocal networking - guanxi. In contrast to blat as a reaction to the Soviet economy, guanxi dates back to the pre-Socialist period. Several authors acknowledge there are many similarities between the blat and guanxi as a 'survival kit' or 'safety network' (Hsu 2005; Ledeneva 2008). Both are reciprocal, informal, and based on delayed reciprocity. Gradual differences are, however, more important. Guanxi, as blat, is a network and practice that constantly changes its forms. There are, nevertheless, certain features that characterize most variations of guanxi. First of all, guanxi is an inclusive and constantly expanding network. At its core, guanxi is based on kinship ideology, linking both biological and fictive kin. This network channels not only the transmission of goods and money, but also favors. In fact, some scholars argue how the most important part of guanxi is indeed the 'small favors', which are sometimes exchanged in a highly ritualistic way.

\section{RELUCTANT ENTREPRENEURS}

Below are presented several cases from the pool of informants. Each individual has his or her own reasons to be an entrepreneur, but there are also common features and attitudes making them part of a distinct group of entrepreneurs in the Republic of Sakha. 
Alena is in her late thirties, and works as a book-keeper in municipal government structures, where she earns her main income, as does her husband. They, nevertheless, see themselves principally as managers of a fishing enterprise. The enterprise is located on the coast of the Arctic Ocean, in Tiksi, a former military settlement, and a big Soviet-era trade port. Alena's mother established the fishing enterprise in the mid-1990s and since then it has existed as a family enterprise. All employees of the small enterprise are family members and the purpose of the enterprise has always been guaranteeing kin people with an income. The northern fish is considered a delicacy in the Republic of Sakha and has traditionally been in high demand in the southern cities. In recent years the market has, however, been overflooded. Ten years ago the northern fish was difficult to acquire in Yakutsk, today markets and street corners are literally full of street vendors who sell such fish. The prices have fallen and fishing enterprises are struggling to make ends meet. Alena is taking care of marketing and all the paperwork (licenses, taxes, state subsidies) whereas her husband is organizing the transport of the catch to Yakutsk. This requires certain skills and good connections. The fish is usually bought by state and private enterprises, and the prices vary. When Alena sells the catch to a state enterprise then she is entitled to state subsidies, but she said that the private buyers pay more. Therefore, to have the optimal outcome, costs for transport should be calculated carefully, and also the paperwork needed to sell fish legally. Both - Alena and her husband - admit that they do not earn much when managing the enterprise, as the priority is to pay salaries for their relatives in Tiksi, and also obtain supplies for the fishing season. When I asked Alena why she was engaged in the enterprise at all, she gave me a long stare and said: "How can I give up an enterprise that my mother established? And what will happen to all the people?" (personal communication, 2013) While managing the fishing enterprise, Alena has also tried other activities. For many years she ran a French-style café, offering pastries and different coffees. She quit when she had problems finding skilled workforce to maintain the quality of the products. This café was also a route for many of her rural-origin relatives to start a new life in the city. This was problematic because young relatives often left unexpectedly when they managed to find a more respectable and well-paid job.

Marfa is in her mid-fifties, and has a laundry in an old Soviet concrete block district of Yakutsk. She was previously a daycare teacher, but when in the early nineties wages were not paid in Russia, she decided to open a kiosk selling everything from beer to cheap jewelry, to cleaning liquid, akin to tens of thousands of kiosks in Russia. Marfa struggled hard to support her family and raise her son. Over time her business did well and she opened more kiosks. In the mid-2000s she was offered some laundry machines and so she switched 
occupation. Located in the basement of a tenement building, there was no sign for the laundry, which surprised me. The reason is that Marfa finds customers only via word of mouth or through personal contacts. In recent years Marfa has found valuable customers such as restaurants needing to wash their tablecloths regularly. The enterprise hires only a few female pensioners, as a rule, illegally, i.e., not registered and taxes unpaid. Marfa sees it as a kind of charity, assistance for pensioners in need of money. Her son helps with managing the laundry and has opened a workshop in a garage on the property where they both live. He repairs cars and motorcycles, also not paying any taxes. Marfa is also a coowner of a shop in one of the northern villages. Another owner is her sister, and Marfa's task is to buy and organize transport for different goods to be sold in the village. Both have decided not to sell alcohol, despite the fact that this is the easiest way to make a profit in remote northern settlements. "We do not support it [alcohol consumption]! We support ZOZh!"6 (Marfa, personal communication, 2013)

Ivan is in his late fifties and lives in the remote northern village of Saidy. Saidy is located in the Verkhoyansk district and can be reached only by a 4-8hour motorboat trip from the district center in the summertime. In winter, when the river is frozen, trucks use it as a winter road. Approximately 700 people live in the village, a settlement of cattle herders, hunters, and fishers, with a strong sense of community. Even for a remote Arctic village, Saidy has an extraordinarily strong informal economy. Most of the hunting, transport service, cattle husbandry, and fishing is on an informal basis. Fish, milk, and meat are sold without any official record. The village has no official shops selling food and other consumables, and all three existing shops are technically illegal. A few years ago the community decided to ban the sale of alcohol in the village, and as the head of the village administration told us, they decided to allow the shops to exist under the condition they did not sell any alcohol. Ivan got into shop-keeping accidentally. His son-in-law, who is an entrepreneur in Yakutsk, learned how shops are run illegally in Saidy, without any license, registration or other paperwork. He suggested that Ivan opens a shop and delivers supplies directly from Yakutsk. Ivan's shop - and all the other shops - look like any other ordinary multifunctional store: shelves, price labels, and a freezer in the corner. Ivan's shop is well stocked, regular foodstuff, cigarettes, and clothes, he even sells red caviar and expensive cheese. All the goods are delivered from Yakutsk; the profit is split with the son-in-law. Ivan is officially an unemployed pensioner, but in reality a full-time shopkeeper. Nevertheless, he seems to be not too enthusiastic about his current career. "There is no work in the village. This is why young people leave. Someone of my age, I have no place to go. Everything costs money, so you need a job. This job is as good as any other. Sure, it would be better if it paid my pension..." (Ivan, personal communication, 2014). 
Sveta is in her late thirties and works as a sports teacher at a school in Yakutsk. She is also a fully licensed trader and entrepreneur. She needs the license to buy goods for her sister's shop in a village in the north central district of the republic. Thanks to the license, Sveta can officially hire trucks to send the ordered goods to the village. The document also entitles her to buy goods from wholesalers. Alongside being the supplier for her sister, Sveta has her own small additional income in the village where most people are related by kinship ties.

Sometimes people ask me to buy something. Like a fridge or furniture. Sometimes very specific clothes or ... when they order these things I usually send them to the village by truck. I do it almost for free. Let's say, I take 1000 rubles for buying a fridge. It is not that much, rather a symbolic amount because a fridge costs a lot. And organizing transport takes time. (Sveta, personal communication, 2014)

In general, Sveta engages in her own small private business because she can send the ordered goods using the trucks she fills with consumables for her sister's shop. There exists a practical agreement between her and her sister, and the village community. Both women know most of the village population and are linked to them via various kinship ties or common biography - they went to school together, played together as children, were long-time neighbors, their parents were friends, and so forth. Sveta can send bigger items, like fridges, to the village when there is free space on the truck. While Sveta's sister does not earn anything from their enterprise, people can become impatient and ask her how long they have to wait for a thing they have already paid for. Therefore, in order to stay on good terms with the neighbors, the sister has to allow the transportation of certain items, even when she could use the place on the truck for things for the shop. As Sveta told me: "It is sometimes difficult to distinguish whether you help your old childhood friend or make business" (personal communication, 2013). Answering my question about why people prefer to order certain goods from her and not her sister, Sveta replied that it was faster and easier to ask someone for that kind of favor: "I can always run and buy that cupboard or jacket when going to school or after the lessons. Otherwise it would be on the order list and it could take few truck loads before it arrives" (personal communication, 2013). She was adamant that she would continue to work as a schoolteacher:

It is good to be in a state job. You have all the bonuses [Rus. 'Igoty'] like one free trip inside Russia for a vacation, insurance, sick leave compensation and some more benefits that one does not have when working for a private entrepreneur. (ibid.) 


\section{TRUST, MORALITY, AND RESPONSIBILITY}

Russia is described as a society of strong interpersonal trust based on networks (Gibson 2001) in an economic environment where "honesty does not pay" (Radaev 2005: 114). On the other hand, small and medium-size businesses are adept at being engaged in an informal and illegal economy in order to "escape state regulations on production and transactions" or to absorb risks (Beneria 1989: 184). The question that remains is whether we can interpret the semiinformal economic networks of Sakha entrepreneurs in neo-classical terms, as a strategy to increase profit to the maximum? The described case studies, and other cases I encountered, have one common feature: their owners want to keep as far away as possible from the state structures. Entrepreneurs tend to be skeptical about the state but their skepticism is caused rather by the system of social norms than by the attitudes or politics of state institutions (cf. Nee \& Young 1991: 297). Many scholars and commentators admit that Russia is not the friendliest country for entrepreneurship (Agarwal 2007; Berkowitz \& DeJong 2001; Gustafson 1999; Hedlund 1999). In the Republic of Sakha, the relationship between entrepreneurship and the state is, however, unexpectedly calm. In some interviews I asked the entrepreneurs whether the state tax officials ever show any interest in small enterprises. Marfa explained that in the Republic of Sakha tax officials largely ignore small and medium-size enterprises. "They receive a certain percentage from any fine they extract from the enterprises. The situation is that the fines are much bigger when you deal with big companies. In our case it makes a few thousand rubles and is not worth it" (personal communication, 2013). This was also confirmed by the former Minister of Economy of the republic, Aleksandr Kugaevskii. He explained that by law the tax officials receive a certain financial bonus according to how much they contribute to the republic's budget. Local economists explain such a policy with the economic priorities of the republic. The main attention of the state institutions is on big companies as major cash cows. Smaller enterprises are not very interesting for the state because they do not produce much, and are just economic interlocutors. Simultaneously, due to the low purchase power of the population, incomes of small enterprises are insignificant from the point of view of the state (Egorov 2006: 188, 192). The entrepreneurs certainly have to cope with corruption, bribe their way through the bureaucracy, or 'support' a local police officer financially. They, however, do not wish to have access to the state resources and wish for the minimum attention from the state institution. The impression is that the reluctant entrepreneurs reduce their contact with state structures to a minimum, and in some cases even operate in unmarked buildings without any public advertisement. Therefore, the practice applied by 
entrepreneurs under study is not "to secure personal benefits for the members of one's circle at the expense of the state" (Hsu 2005: 321; Peng \& Shekshnia 2001 ) but to avoid access to state resources and this way avoid contact with state institutions. Such a 'guerilla strategy' helps to maintain entrepreneurial 'flexibility' (Peng \& Shekshnia 2001), which is realized by diversification of risks through expanding into other spheres and establishing economically non-related new enterprises. Combining laundry with car repair or selling food products, yet staying small, helps to keep the business within the family without hiring outside managers. This and other aspects make the concept of blat, as stressed above, unsuitable for the current situation.

The research data suggests that while blat is rather an exclusive reciprocal circle, the networks I studied are inclusive or constantly expanding. The case studies referred to above (and others I did not mention) show the incorporation of new members, or using the existing kin-based contacts characteristic of the Chinese guanxi. Illuminating is a discussion I witnessed in one of my friend's office in December of 2013. When we were having a cup of coffee, the door opened and an elderly woman entered. She asked Gosha (the friend) whether he knew a hairdresser for a barber's salon. The subsequent chat revealed that the woman was an entrepreneur with a long history in local private businesses. She constantly switched from one occupation to other, expanding or closing enterprises according to how successful they were. She had started out like many of the entrepreneurs I met, as a trader on a market, then opened a small kiosk, was the first entrepreneur to start a small workshop producing toilet paper, and so on. At the moment of meeting me she had progressed to a corner shop business but also had two hairdresser's salons, one for women and another one for men. The reason why she had popped into Gosha's office was that they came from the same district. "Because we came from the same district and neighboring villages, we are like kinfolk. We are supposed to help each other. She knows I know many people and there is a possibility I can help" (Gosha, personal communication, 2013).

Sakha kin relationships are sometimes very confusing. In general, Sakha families nurture strong reciprocal ties between different generations, linking relatives living in various villages and towns. The biological kinship network is usually extended by fictive kin that can be, for instance, daughter's best friend or father's schoolmate (see also Ventsel 2005). Boundaries are even more blurred by the widespread tradition of adoption, where an adopted child will also maintain close ties with his or her biological parents. Notwithstanding the fact that a modern Sakha extended family stretches over several districts, the district of origin plays a crucial role in identification. According to existing 
social norms, people originating from one district should support each other whenever possible and in reality such support is often practiced. ${ }^{7}$

This practice is similar to the Chinese guanxi, constantly expanding networks on the basis of finding 'common ground' (Puffer \& McCarthy \& Boisot 2010: 455). Contrary to the 'comparatively narrow definition of friendship' in blat networks, the guanxi practice absorbs new members, and parallel to kinship ties there are instrumentalized friendship and fictive kin relationships (Hsu 2005: 321-322). Scholars argue that such a strategy makes guanxi more ritualized but also more predictable (Ledeneva 2008: 128). In the Sakha case, the solidarity and loyalty of actors is ideologically motivated by the stressing of a common territorial origin or family. The abovementioned discussion between Gosha and the lady entrepreneur started with a general exchange of news about relatives and life in the village, stressing their common origin. Such an ideology makes it possible to find help and provide support to new members often personally unknown to the actors. Similar to guanxi, Sakha entrepreneurs use their 'connections' not only to gain access to resources or negotiate business deals, but quite often to ask for favors. Despite the fact that the practice of exchanging favors is widespread in Russia and such 'small favors' help to cement reciprocal relationships, in modern times they are often related to the flow of cash (Humphrey 2012). The 'small gestures' strategy is common also in Chinese guanxi but it does not necessarily lead to a monetary transaction (Strickland 2010: 111). In the Sakha practice, favors are often returned with favors and mutual trust plays a central role in such exchanges. It must be mentioned that such an exchange of favors was even embedded in this research, because all the entrepreneurs I interviewed agreed to meet us as a response to a request from our common friends. Another expression of trust is looking for new employees using the network. This is based on the belief that exists in China where a guanxi friend is a good source to find a trustful employee (Puffer \& McCarthy \& Boisot 2010: 454-456). This contradicts with blat where friends of friends are treated with suspicion and such links tend to be used in a more contractual manner, i.e., favors and their prices are negotiated in advance (see Humphrey 2012; Ledeneva 2008).

As I have shown, Sakha entrepreneurial networks stretch geographically over several thousand kilometers and cover certain 'gray areas' (Chang 2011: 328), such as running illegal shops or hiring staff without informing the tax officials. The functioning of these networks, however, maintains a certain moral aspect that tends to contradict pure economic calculus. In the case of Alena, Marfa, Sveta, and Ivan, entrepreneurship involves a strong ideology of kinship reciprocity. In order to keep the business predictable and stable, they submit to earn less profit. The obligation of responsibility for kin people's wellbeing 
is especially obvious in Alena's fishing enterprise, but it is also apparent with many other entrepreneurs. Most interesting is the decision of the shop owners not to sell alcohol. In general, the entrepreneurs take an active position in what they think is in the community's interests. All entrepreneurs could have made huge profits by selling alcohol either legally or illegally, as is the widespread practice in northern villages. The refusal to sell alcohol is a powerful statement. Alcohol consumption in indigenous communities is a fiercely debated issue in the Republic of Sakha and is connected with the debate about the 'health of a nation' and 'maintaining the traditional way of life' (Krivoshapkin-Aiynga 1998; Lapparova 2002; Tyrylgin 2000). There is a need for more research on the topic but here 'supporting ZOZh' means adopting a larger framework of moral categories and shaping business strategies specifically. In some cases, like for Ivan in Saidy, it means following the community's decision to forbid the sale of alcohol in the village, but in all cases opposing the sale of alcohol signals a commitment to shared values and a readiness to disclaim 'dirty money' earned by harming the community. This step should not be interpreted as a cynical business strategy with leverage in the eyes of the community or as a purely altruistic move. Some of the informants truly believe that this is their contribution to the development of the community and to the future of the Sakha in general. Here the parallel could be drawn with the tradition of guanxi, based on a pre-socialist tradition of reciprocity and Chinese customs (Hsu 2005; Strickland 2010).

\section{CONCLUSION}

I think that the term 'reluctant entrepreneurs' is appropriate for a particular group of Sakha entrepreneurs because in many aspects their entrepreneurial biography and business morals contradict the profit-oriented neo-classical model of economy. This group of entrepreneurs is also hard to conceptualize in the academic understanding of blat, which to date dominates the research on Russian private entrepreneurs. In order to understand the nature of the group under study, one should also have some understanding about the regional economy in the Republic of Sakha. This is an environment where, notwithstanding the rhetoric, the regional government shows little interest in supporting small and medium-size enterprises. The focus of local economic policy is on big companies who in one way or another contribute the lion's share of the local budget. Therefore, small enterprises, despite the fact that they provide jobs for a significant part of the local labor force, are left to survive on their own terms. 
The 'reluctant entrepreneurs' are businesswomen and -men who entered the occupation largely out of necessity due to the economic chaos in Russia during the 1990s. In many cases they are not even today overtly convinced of the durability of their choice. Indicative is the fact that most entrepreneurs I have studied either maintain their state-paid jobs, or plan to return to the public sector before their retirement. Why they remain entrepreneurs is often due to a moral obligation, a lack of state-paid jobs, and the economic uncertainty in Russia which has increased after 2014.

It is interesting to look at the moral framework of these Sakha entrepreneurs. Here we can find a sense of moral obligation to kin and older people, responsibility for the community and one's own people at large. These aspects make the Chinese guanxi better suited as an analytic framework to discuss the 'reluctant entrepreneurs'. The emphasis on tradition, extended kinship, trust, and non-monetary reciprocity is common to the Sakha and Chinese cases. Moreover, as is the Sakha case under study, Chinese guanxi means open and constantly expanding networks in contradiction to the relatively closed circles of blat. The segment of entrepreneurs I called reluctant demonstrates that there are different ways of doing business in Russia and therefore a need for a conceptually more pluralistic approach.

\section{ACKNOWLEDGEMENTS}

This research was supported by the institutional research funding IUT 34-32 of the Estonian Ministry of Education and Research.

\section{NOTES}

1 The illustration for the ambivalence of the classification is a construction firm in Yakutsk. The enterprise has less than 15 permanent workers, which makes it a 'microenterprise'. These permanent workers are mainly engaged in management tasks. When the enterprise, however, signs a building contract, they hire dozens of construction workers from the former Soviet Central Asian republics or from Sakha villages, depending on the profile of the task - wooden buildings are mainly built by the Sakha whereas managers believe that the Kyrgyz and Uzbek are better suited for constructing concrete buildings.

2 The recordings of the interviews are in possession of the author of the article. All names of the informants were changed to guarantee their anonymity.

3 See criticism over the use of neoclassical theory in the analysis of post-socialist entrepreneurship in Estrin \& Aidis \& Mickiewicz (2006: 4) and Kuznetsov \& Kuznetsova (2005). 
4 This kind of approach is not unique to Russian studies. For instance, in the case of East Germany or the former GDR, one can still find researchers who see the region as static and unchanging, and complain about the 'existing GDR mentality' that hinders successful transformation, or view new private enterprises as something 'new' (Böhmer 2005).

5 The best source for current corruption scandals involving state officials or institutions is the website of a well-known Russian opposition figure, Alexei Navalny (see navalny. com).

${ }^{6}$ Zdorovye obraza zhizni or Healthy Ways of Life is a loose campaign in Russia promoting abstinence from alcohol and tobacco, combined with active ways of life such as engagement in sports.

7 The average Sakha greeting between two strangers is "Khantan syld'an?" (Where are you from?). It means that already at the beginning of a meeting strangers make sure of the district and kin affiliation of the interlocutor. Most Sakha, even when they are second- or third-generation urban dwellers, trace their origin back to some district and nurture that connection by hosting rural relatives when they come to the city (for example, on shopping trips). Rural relatives usually respond by taking with them 'village food' - meat, milk products or berries.

\section{REFERENCES}

Agarwal, Manmohan 2007. International Economic Management: Concerns of China, India, Russia. China Report, Vol. 43, No. 2, pp. 163-173. http://dx.doi. org/10.1177/000944550704300205.

Alanen, Ilkka \& Nikula, Jouko \& Põder, Helvi \& Ruutsoo, Rein (eds.) 2001. Decollectivisation, Destruction and Disillusionment: A Community Study in Southern Estonia. Aldershot: Ashgate.

Barsukova, Svetlana \& Radaev, Vadim 2012. Neformal'naia ekonomika v Rossii: kratkii obzor. [Informal Economy in Russia: Short Overview.] Ekonomicheskaia sotsiologiia, Vol. 13, No. 2, pp. 99-111. Available at https://ecsoc.hse.ru/2012-13-2. html, last accessed on 29 November 2018.

Beneria, Lourdes 1989. Subcontracting and Employment Dynamics in Mexico City. In: Alejandro Portes \& Manuel Castells \& Lauren A. Benton (eds.) The Informal Economy: Studies in Advanced and Less Developed Countries. Baltimore \& London: The John Hopkins University Press, pp. 173-187.

Berkowitz, Daniel \& DeJong, David 2001. Entrepreneurship and Post-Socialist Growth. William Davidson Institute Working Paper Number 406. Available at https:// pdfs.semanticscholar.org/dfc4/b7c2c2fb2734766caa150d1881dc09c282a4.pdf, last accessed on 20 November 2018.

Böhmer, Robert 2005. Der Geist des Kapitalismus und Aufbau Ost. Dresden: Thelem.

Cartwright, Andrew L. 2001. The Return of the Peasant: Land Reform in Post-Communist Romania. Aldershot: Ashgate. 
Chang, Kuang-Chi 2011. A Path to Understanding Guanxi in China's Transitional Economy: Variations on Network Behavior. Sociological Theory, Vol. 29, No. 4, pp. 315-339. http://dx.doi.org/10.1111/j.1467-9558.2011.01401.x.

Davidova, Sophia \& Thomson, Kenneth J. 2003. Romanian Agriculture and Transition toward the EU. Lanham \& Boulder \& New York \& Oxford: Lexington Books.

Egorov, Egor G. 2006. Sever Rossii: ekonomika, politika, nauka. [Russian North: Economy, Politics, Science.] Yakutsk: Sakhapoligrafizdat.

Estrin, Saul \& Aidis, Ruta \& Mickiewicz, Tomasz 2007. Institutions and Entrepreneurship Development in Russia: A Comparative Perspective. William Davidson Institute Working Paper Number 867, February 2007. Available at https://core. ac.uk/download/pdf/3119230.pdf, last accessed on 29 November 2018.

Gambold Miller, Liesl L. 2003. Interdependence in Rural Russia: The Postsocialist Mixed Feudal Economy. Max Planck Institute for Social Anthropology: Working Papers, No. 51. Halle/Saale: Max Planck Institute for Social Anthropology. Available at https://www.eth.mpg.de/cms/en/publications/working_papers/wp0051, last accessed on 26 November 2018.

Gibson, James L. 2001. Social Networks, Civil Society, and the Prospects for Consolidating Russia's Democratic Transition. American Journal of Political Sciences, Vol. 45, No. 1, pp. 51-68. http://dx.doi.org/10.2307/2669359.

Gustafson, Thane 1999. Capitalism Russian-Style. Cambridge \& New York: Cambridge University Press.

Hann, Chris M. 2000. The Tragedy of the Privates? Postsocialist Property Relations in Anthropological Perspective. Max Planck Institute for Social Anthropology Working Papers, No. 2. Available at https://estudiscritics.files.wordpress.com/2011/02/ chris_hann_postsocialismo1.pdf, last accessed on 23 November 2018.

Hedlund, Stefan 1999. Russia's “Market” Economy: A Bad Case of Predatory Capitalism. London: UCL Press.

Hsu, Carolyn L. 2005. Capitalism Without Contracts versus Capitalists without Capitalism: Comparing the Influence of Chinese Guanxi and Russian Blat on Marketization. Communist and Post-Communist Studies, Vol. 38, No. 3, pp. 309-327. http://dx.doi.org/10.1016/j.postcomstud.2005.06.003.

Humphrey, Caroline 2000. An Anthropological View of Barter in Russia. In: Paul Seabright (ed.) The Vanishing Rouble: Barter Networks and Non-Monetary Transactions in Post-Soviet Societies. Cambridge \& New York: Cambridge University Press, pp. 71-92.

Humphrey, Caroline 2002. Rituals of Death as a Context for Understanding Personal Property in Socialist Mongolia. Journal of the Royal Anthropological Institute, Vol. 8, No. 1, pp. 65-87. https://doi.org/10.1111/1467-9655.00099.

Humphrey, Caroline 2012. Favors and "Normal Heroes": The Case of Postsocialist Higher Education. HAU: Journal of Ethnographic Theory, Vol. 2, No. 2, pp. 22-41. https:// doi.org/10.14318/hau2.2.003.

Köllner, Tobias 2013 [2012]. Practising Without Belonging? Entrepreneurship, Morality, and Religion in Contemporary Russia. Berlin \& Münster \& Wien \& Zürich \& London: LIT Verlag.

Krivoshapkin-Aiynga, Andrei 1998. Evraziiskii soiuz. [Eurasian Union.] Yakutsk: Bichik. 
Kuznetsov, Andrei \& Kuznetsova, Olga 2005. Business Culture in Modern Russia: Deterrents and Influences. Problems and Perspectives in Management, Vol. 3, No. 2, pp. 25-31. Available at https://businessperspectives.org/journals/problemsand-perspectives-in-management/issue-7, last accessed on 29 November 2018.

Lapparova, I. F. 2002. Sotsial'nye posledstviia promyshlennogo osvoeniia Iakutii v raionakh prozhivaniia korennykh malochislennykh narodov Severa (konets $50 \mathrm{kh}-$ 80e gg.). [Social Consequences of the Industrial Mastering in Yakutia in the Districts of Compact Settlement of Small Indigenous People of the North (End of the 50s-80s.] In: A. Kardashevskaia \& E. Vasil'eva \& I. Lapparova (eds.) Malochislennye etnosy severa Respubliki Sakha (Iakutiia) glazami molodykh uchenykh. Yakutsk: IPMNS SO RAN, pp. 15-20.

Ledeneva, Alena V. 1998. Russia's Economy of Favours: Blat, Networking and Informal Exchange. Cambridge: Cambridge University Press.

Ledeneva, Alena V. 2006. How Russia Really Works: The Informal Practices That Shaped Post-Soviet Politics and Business. Ithaca \& London: Cornell University Press.

Ledeneva, Alena 2008. Blat and Guanxi: Informal Practices in Russia and China. Comparative Studies in Society and History, Vol. 50, No. 1, pp. 118-144. http:// dx.doi.org/10.1017/S0010417508000078.

McCarthy, Daniel J. \& Puffer, Shelia M. \& Shekshnia, Stanislav V. 1993. The Resurgence of an Entrepreneurial Class in Russia. Journal of Management Inquiry, Vol. 2, No. 2, pp. 125-137. http://dx.doi.org/10.1177/105649269322002.

Nee, Victor \& Young, Frank W. 1991. Peasant Entrepreneurs in China's "Second Economy": An Institutional Analysis. Economic Development and Cultural Change, Vol. 39, No. 2, pp. 293-310. http://dx.doi.org/10.1086/451871.

Peng, Mike W. \& Shekshnia, Stanislav V. 2001. How Entrepreneurs Create Wealth in Transition Economies. The Academy of Management Executive, Vol. 15, No. 1, pp. 95-110. http://dx.doi.org/10.5465/ame.2001.4251397.

Pickles, John \& Smith, Adrian (eds.) 1998. Theorising Transition: The Political Economy of Post-Communist Transformations. London \& New York: Routledge.

Polischuk, Leonid 2001. Small Businesses in Russia: Institutional Environment. University of Maryland, Iris Working Paper No. 240. Available at https://papers.ssrn. com/sol3/papers.cfm?abstract_id=260042, last accessed on 26 November 2018.

Puffer, Sheila M. \& McCarthy, Daniel J. \& Boisot, Max 2010. Entrepreneurship in Russia and China: The Impact of Formal Institutional Voids. Entrepreneurship Theory and Practice, Vol. 34, No. 3, pp. 441-467. http://dx.doi.org/10.1111/j.15406520.2009.00353.x.

Radaev, Vadim 1998. Formirovanie novykh rossiiskikh rynkov: transaktsionnye izderzhki, formy kontrolia i delovaia etika. [Formation of Russian Markets: Transaction Costs, Forms of Control, and Business Ethics.] Moscow: Tsentr politicheskikh tekhnologii.

Radaev, Vadim 2005. Establishing Trust in a Distrustful Society: The Case of Russian Business. In: Hans-Hermann Höhmann \& Friederike Welter (eds.) Trust and Entrepreneurship: A West-East Perspective. Cheltenham, UK: Edward Elgar, pp. 114-135. 
Rasell, Michael 2009. Neoliberalism in the North: The Transformation of Social Policy in Russia's Northern Periphery. Polar Geography, Vol. 32, No. 3-4, pp. 91-109. http://dx.doi.org/10.1080/10889370903471292.

Sakaeva, Maria M. 2012. Parlament kak “okno vozmozhnostei': issledovanie povedeniia predprinimatelei s deputatskim mandatom $\mathrm{v}$ khode realizatsii rynochnykh interesov. [Parliament as a "Window of Opportunities".] Ekonomicheskaia sotsiologiia, Vol. 13, No. 3, pp. 96-122. Available at https://ecsoc.hse.ru/2012-13-3. html, last accessed on 30 November 2018.

Shlapentokh, Vladimir 2007. Contemporary Russia as a Feudal Society: A New Perspective on the Post-Soviet Era. New York, Houndmills: Palgrave Macmillan. DOI: 10.1057/9780230609693.

Ssorin-Chaikov, Nikolai 2000. Bear Skins and Macaroni: The Social Life of Things at the Margins of a Siberian State Collective. In: Paul Seabright (ed.) The Vanishing Rouble: Barter Networks and Non-Monetary Transactions in Post-Soviet Societies. Cambridge: Cambridge University Press, pp. 345-361.

Stark, David 1991. Path Dependence and Privatization Strategies in East Central Europe. East European Politics and Societies: and Cultures, Vol. 6, No. 1, pp. 1754. https://doi.org/10.1177\%2F0888325492006001003.

Stepanova, N. A. \& Nogovitsyn, R. R. 2011. Maloe predprinimatel'stvo Severnogo regiona $v$ usloviiakh perekhoda na innovatsionnyi put' razvitiia. [Small Businesses in the Northern Region during Transition to Innovative Development.] Yakutsk: Sfera.

Strickland, Michael 2010. Aid and Affect in the Friendships of Young Chinese Men. Journal of the Royal Anthropological Institute, Vol. 16, No. 1, pp. 102-118. http:// dx.doi.org/10.1111/j.1467-9655.2009.01599.x.

Tarasov, M. E. \& Egorov, E. G. \& Kulakovskii, G. P. 2013. Vliianie tenevoi ekonomiki na ekonomicheskuiu bezopasnost' regiona: monografiia. [The Impact of Shadow Economy on the Economic Security of the Region: Monograph.] Yakutsk: SeveroVostochnyi federal'nyi universitet.

Tyrylgin, Mikhail A. 2000. Istoki fenomenal'noi zhiznesposobnosti naroda Sakha. [Sources of Phenomenal Vitality of the Sakha.] Yakutsk: Bichik.

Ventsel, Aimar 2005. Reindeer, Rodina and Reciprocity: Kinship and Property Relations in a Siberian Village. Halle Studies in the Anthropology of Eurasia, Book 7. Berlin: LIT Verlag.

Verdery, Katherine 1993. Ethnic Relations, Economies of Shortage, and the Transition in Eastern Europe. In: Chris M. Hann (ed.) Socialism: Ideals, Ideologies, and Local Practice. London \& New York: Routledge, pp. 172-186.

Verdery, Katherine 1996. What Was Socialism, and What Comes Next? Princeton, New Jersey: Princeton University Press.

Wegren, Stephen K. 2000. Socioeconomic Transformation in Russia: Where Is the Rural Elite? Europe-Asia Studies, Vol. 52, No. 2, pp. 237-271. http://dx.doi. org/10.1080/09668130050006781. 